\title{
Communication
}

11

[Comunicação]

\section{Changes in surface temperature of upper fore and hindlimbs of horses submitted to four beat gait exercise determined by thermography}

\author{
[Alterações de temperatura superficial dos membros torácicos e pélvicos termograficamente \\ determinados em cavalos submetidos ao exercício de marcha] \\ A.R. Teixeira Neto ${ }^{1}$, J.R.M. Pereira ${ }^{2}$, A.B. Santos ${ }^{2}$, R.M. Almeida ${ }^{1}$, B.S.L. Dallago ${ }^{2}$ \\ ${ }^{1}$ Hospital Veterinário - Universidade de Brasília - Brasília, DF \\ ${ }^{2}$ Faculdade de Agronomia e Medicina Veterinária - Universidade de Brasília - Brasília, DF
}

\begin{abstract}
Originally from Brazil, the Mangalarga Marchador breed has a natural four-beat gait instead of a trot (Lima et al., 2006; Jordão et al., 2011). Despite being used in several functions such as long-distance journeys, cattle work, and others, the true expression of the breed is the "march", with a competition to evaluate the horse functionally (Abrantes et al., 2015). In this competition, the horses are submitted to a longdistance effort with speeds varying from 9 to $12 \mathrm{~km} . \mathrm{h}^{-1}$, lasting from 20 to 70 minutes (Prates et al., 2009).
\end{abstract}

Some studies revealed that thermography is a noninvasive diagnostic technic that can detect body heat emission through infrared radiation and determine the superficial body temperature of the animal (Stewart et al., 2005). Physical exercise produces net heat since only 20 to $25 \%$ of the energy used by the muscle is converted to mechanical energy (Hyyppa and Poso, 2004). During exercise, metabolic heat production increases with increasing exercise intensity (Mckeever, 2004). To understand exercise and the influence of exertion on thermographic images of clinically normal horses requires using thermography appropriately (Simon et al., 2006). In this context, the present study used thermography to evaluate whether the superficial temperature of upper fore and hindlimbs of Mangalarga horses increased as a result of heat production during a four-beat gait exercise at $15 \mathrm{~km} . \mathrm{h}^{-1}$ for 20 minutes.

Twenty-five healthy horses (12 gelding and 13 mares) aged $6.5 \pm 3$ years and weighing $414.9 \pm 34.5 \mathrm{~kg}$ on average were used in this study. The horses came from the same stud farm where the experiment was conducted, in the midwest region of Brazil $\left(15^{\circ} 55^{\prime} 23.5^{\prime \prime} \mathrm{S}\right.$ and $\left.48^{\circ} 07^{\prime} 41.4^{\prime \prime} \mathrm{W}\right)$. The protocol was approved by the Ethics Committee on Animal Use from Brasilia University (CEUA-UnB), 55/2018. The animal owner signed a formal consent approving the trial.

The horses were fed Cynodon sp. hay, water, and mineral salt ad libitum and grain meals (1\% of body weight), twice a day. They were kept in individual horse stalls measuring $4 \times 4$ meters during the night and free pasture regimen during the day. Before the trial, the horses rested for 24 hours followed by a clinical evaluation that detected no signals of lameness or any other disease. Right before the effort, heartbeat and respiratory rate, as well as rectal temperature, were measured. The same evaluations were repeated 5 and 30 minutes after the exercise protocol was completed. Images were also captured in all described moments, $5 \mathrm{~m}$ perpendicular to the right lateral surfaces of the thoracic and pelvic limbs and caudal surfaces of the pelvic limbs (Figure 1 and 2). No sedation was required at any time and all animals were weightbearing on all four limbs during imaging.

Recebido em 13 de novembro de 2019 

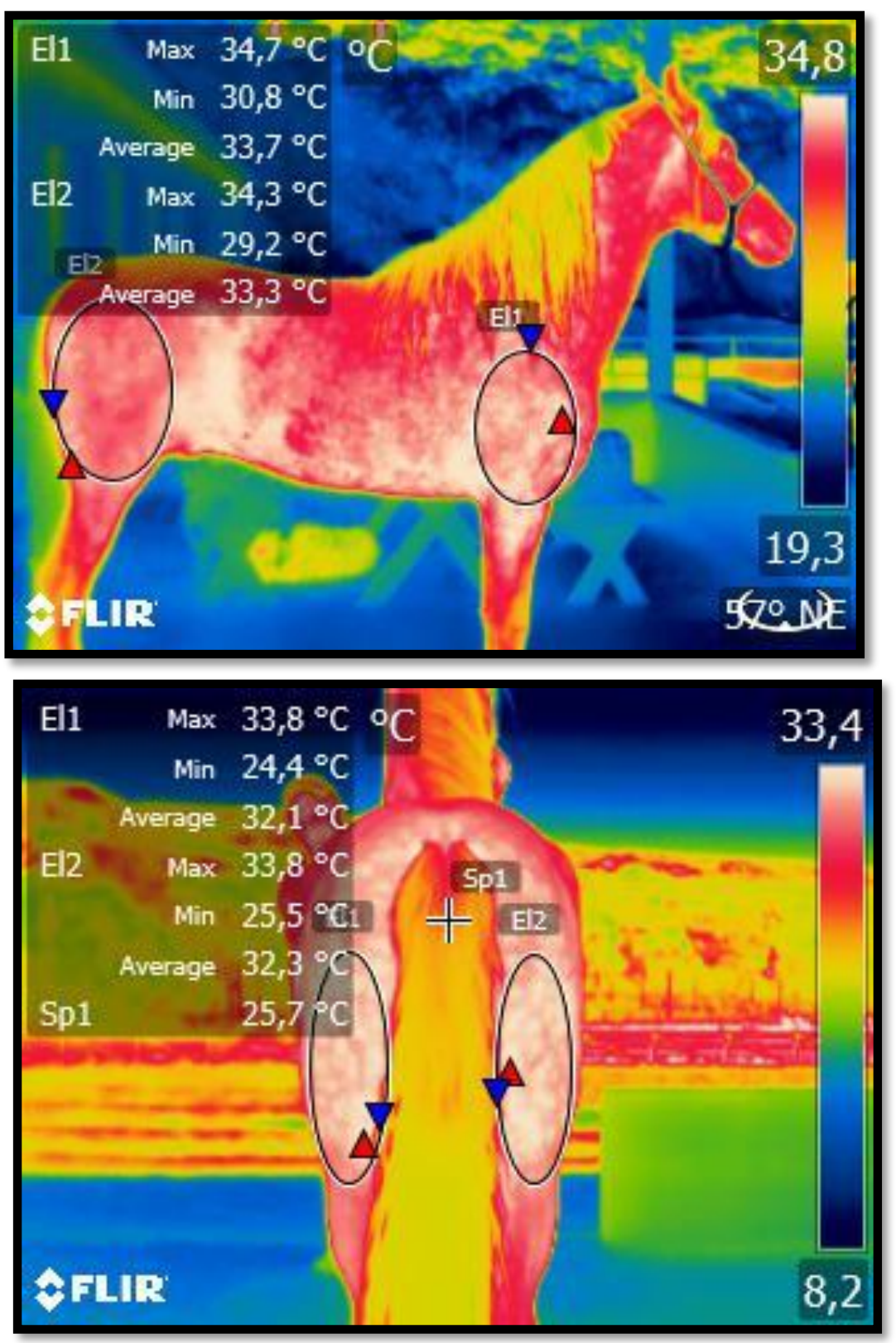

Figure 1. Lateral (A) and caudal (B) infrared thermographic images of Mangalarga healthy horses before four-beat gait exercise. The ellipsis indicate the evaluated areas, related to the upper part of the fore and hindlimb muscles. Red and blue triangles indicate the maximum and minimum surface temperature measurements, respectively.

Data were collected during five days and all images were taken daily between 14:00 and 16:00. Average room temperature and relative humidity of $25^{\circ} \mathrm{C}$ and $37 \%$, respectively, were measured in real-time using a digital meteorologic station (Instrutemp®, ITWH-1080) mounted in the imaging room. The thermal imaging equipment consisted of a high-resolution radiometric infrared camera (Flir $\mathrm{T}-460^{\circledR}$ ) and the images were analyzed by the Flir T198583Tool ${ }^{\circledR}$ analytical software. Surface temperatures of the upper fore and hindlimbs were measured in the area inside the ellipsis before (baseline) and immediately after the exercise, and after a 30-minute resting period. 
The obtained data were submitted to descriptive statistical analysis and the Shapiro-Wilk normality test. A one way rmANOVA was employed to compare the physiological values (HR, RR, T), average maximum body temperatures before and five minutes after the exercise as well as after a 30-minute resting period. The IBM SPSS Statistics program for Mac, version 23 (IBM Corp., Armonk, N.Y., USA) was used at a $5 \%$ significance.

All horses successfully completed the exercise protocols and the recovery period without complications. The exercise was performed in a $250 \mathrm{~m}$ long oval track with a surface covered with a $2 \mathrm{~cm}$-thick layer of sand. The exercise simulated a four-beat gait contest that covered a $5 \mathrm{~km}$ distance at $15 \mathrm{~km} \cdot \mathrm{h}^{-1}$ in the oval-shaped circuit and 10 minutes in each direction.

Right after the exercise, the heart rate increased $(\mathrm{P}<0.001)$ from $41 \pm 6$ to $99 \pm 14(\mathrm{bpm})$ and the respiratory rate from $24 \pm 9$ to $70 \pm 16 \mathrm{mpm}$. Likewise, after the exercise, the rectal temperature increased significantly compared to baseline values $\quad(\mathrm{P}<0.001), \quad$ from $37.6 \pm 0.4^{\circ} \mathrm{C}$ to $39.1 \pm 0.4^{\circ} \mathrm{C}$. The mean surface temperatures measured on selected points of the fore and hindlimbs did not increase $(\mathrm{P}>0.05)$. After a resting period of 30 minutes, the horses were clinically examined and all variables had returned to baseline levels. The results are shown in Table 1.

Table 1. Mean values $( \pm \mathrm{SD})$ of heart rate, respiratory rate, rectal temperature and surface temperature of upper forelimbs (LFT) and hindlimbs (LHT) in lateral view and right and left hindlimbs in caudal view (CRHT and CLHT) of Mangalarga horses $(\mathrm{n}=25)$ before and after a four-beat gait exercise at $15 \mathrm{~km} . \mathrm{h}^{-1}$ that lasted 20 minutes (Brasília, 2018)

\begin{tabular}{llll} 
& \multicolumn{1}{c}{ Before exercise } & After exercise & \multicolumn{1}{c}{30 min rest } \\
\hline Heart Rate $(\mathrm{bpm})$ & $41 \pm 6$ & $99 \pm 14^{*}$ & $42 \pm 4$ \\
Respiratory Rate $(\mathrm{mpm})$ & $24 \pm 9$ & $70 \pm 16^{*}$ & $22 \pm 8$ \\
Rectal temperature $\left({ }^{\circ} \mathrm{C}\right)$ & $37.6 \pm 0.4$ & $39.1 \pm 0.4^{*}$ & $38 \pm 0.4$ \\
LFT $\left({ }^{\circ} \mathrm{C}\right)$ & $33.4 \pm 1.1$ & $35.6 \pm 1.0$ & $34.2 \pm 1.0$ \\
LHT $\left({ }^{\circ} \mathrm{C}\right)$ & $32.5 \pm 1.2$ & $34.6 \pm 1.0$ & $33.0 \pm 1.0$ \\
CHRT $\left({ }^{\circ} \mathrm{C}\right)$ & $33.5 \pm 1.2$ & $35.6 \pm 1.1$ & $34.1 \pm 0.6$ \\
CLHT $\left({ }^{\circ} \mathrm{C}\right)$ & $33.6 \pm 1.2$ & $35.6 \pm 1.1$ & $33.4 \pm 1.0$ \\
\hline
\end{tabular}

* indicates a significant increase $(\mathrm{P}<0.001)$ compared to baseline values.

The increase of the heart and respiratory rates, together with speed and exercise duration suggest that horses performed prolonged exercise at a low speed, producing mostly aerobic energy that is related to submaximal exercise (Prates et al., 2009; Folador et al., 2014; Trindade et al., 2019).

Thermography appeared to be safe and easy to perform and was not associated with any complications (Simon et al., 2006). Exercise intensity is the primary determinant of the heat production rate. During exercise, metabolic heat production increases as exercise intensity increases (Mckeever, 2004) as indicated by the increase of rectal temperature $(\mathrm{P}<0.001)$ of horses. However, the surface temperatures of the upper fore and hindlimbs were not significantly different between the thermograms obtained before and after exercise $(\mathrm{P}>0,05)$. The maximum temperature values were measured before and after the exercise on limb areas (ellipsis) selected based on the literature. Several authors (Stewart et al., 2005; Yarnell et al., 2014) have reported this methodology as the most reliable, consistent, and with less variance (Simon et al., 2006).

Although some authors reported significant temperature increases in hindlimb muscle surface right after different exercises (Simon et al., 2006; Yarnell et al., 2014; Gerardi, et al., 2019), others could not detect forelimb muscle temperature variation in Quarter horses (Oliveira et al., 2018). In addition, IRT could be used during training programs to ensure muscles are working symmetrically and indicate which terrains or training programs cause an increase in muscle workload (Yarnell et al., 2014; Gerardi, et al., 2019).

Despite a higher metabolic rate, the trained individuals are able to maintain a similar core temperature when compared to the untrained subject, indicating an enhanced ability to dissipate heat (Mccutcheon and Geor, 2008). It could be 
speculated that the thermoregulatory mechanisms of the tested horses were able to dissipate core heat produced by the exercise as indicated by the increase in rectal temperature so that the body surface temperatures remained the same throughout the experiment.

Due to scarce studies on the use of infrared thermography to evaluate Mangalarga horses after four-beat gait exercises, a moderate exercise protocol was designed to verify whether it could cause significant superficial temperature variation and whether the temperature difference between the fore and hindlimbs could be detected thermographically. To this end, the results suggest that the proposed protocol did not increase the body temperature of trained Mangalarga horses enough to be detected by infrared thermography.

Still, the infrared thermographic evaluation was secure and able to detect some changes in the body surface temperature of Mangalarga horses submitted to the four-beat gait exercise. However, because the proposed protocol did not result in significant thermogram increases, further research should be conducted to evaluate the relationship between exercise workload and body surface temperature increase in horses submitted to this effort.

Keywords: equine, magalarga, heat, termoregulation

\section{RESUMO}

No Brasil, Mangalarga Marchador é a raça com o maior número de equinos registrados, um total de 600.000 animais. Devido à falta de estudos termográficos, este estudo buscou avaliar alterações superficiais de temperatura corporal de membros torácicos e pélvicos após o esforço de marcha, usando uma câmera termográfica com infravermelho. O estudo avaliou 25 equinos, com peso médio de $414,9 \pm 34,5 \mathrm{~kg}$ e idade média de 6,5 3 anos. As imagens foram obtidas a cinco metros de distância perpendicular à superfície lateral e caudal do corpo, em uma sala apropriada. Os animais foram submetidos ao exercício de marcha na velocidade de $15 \mathrm{~km} . \mathrm{h}^{-1}$ por 20 minutos. As imagens foram capturadas imediatamente antes e após o esforço, e repetidas após 30 minutos de repouso. As frequências cardíaca e respiratória aumentaram significativamente $(P<0,001)$, comparando-se antes e após o esforço. Embora tenha sido notado também aumento significativo da temperatura retal $(P<0,001)$, as alterações de temperatura superficial dos membros torácicos e pélvicos entre os termogramas obtidos antes e após o exercício não foram significativas $(P>0,05)$. Dessa forma, mais estudos se fazem necessários para avaliar a relação da duração desse esforço e elevação da temperatura corporal.

Palavras-chave: equinos, Mangalarga, calor, termorregulação

\section{REFERENCES}

ABRANTES, R.G.P.; REZENDE, A.S.C.; SANTIAGO, J.M. et al. Validation of a training protocol for marcha contests of the Mangalarga Marchador breed. Biosci. J., v.31. p.1787-1791, 2015.

FOLADOR, J.C.; DRUMOND, B.; SOUZA, V.R.C.; COELHO, C.S. Concentrações séricas de sódio. potássio e cálcio em equinos da raça mangalarga marchador após exercício físico. Arch. Vet. Sci., v.19. p.60-68, 2014.

GERARDI, B.; DENADAI, D.; PEREIRA, M.S. et al. Use of infrared thermography in Quarter Horse submitted to team roping. Pesqui. Vet. Bras., v.39, p.530-537, 2019.
HYYPPA, S.; POSO, A. Metabolic diseases of athletic horses. In: HINCHCLIFF, K.. KANEPS, A.; GEOR, R.J. (Eds.). Equine sports medicine and surgery. London: WB Saunders Co, 2004. p.836-850.

JORDÃO, L.R.; REZENDE, A.S.C.; BERGMAM, J.A.G. et. al. Effect of feed at different times prior to exercise and chelated chromium supplementation on the athletic performance of Mangalarga Marchador mares. Equine Comp. Exerc. Physiol., v.7. p.133-140, 2011.

LIMA, R.A.S.; SHIROTA, R.; BARROS, G.S.C. Estudo do complexo do agronegócio cavalo relatório final. Piracicaba: CEPEA/ESALQ/USP, 2006. 251p. 
MCCUTCHEON, L.J.; GEOR, R.J. stress. In: HINCHCLIFF, K.W.; GEOR, R.J.; KANEPS, A.J. (Eds.). Equine exercise physiology: the science of exercise in the athletic horse. Philadelphia: Elsevier, 2008. p.382-386.

MCKEEVER, K.H. Body fluids and electrolytes: responses to exercise and training. In: HINCHCLIFF, K.; KANEPS, A.; GEOR, R.J. (Eds.). Equine sports medicine and surgery. London:WBSaunders Co, 2004. p.853-869

OLIVEIRA, K.; OLIVEIRA, G.A.C.; SILVA, D.A. et. al. Dinâmica da temperatura da pele de equinos durante atividade física por meio da termografia infravermelha. Braz. J. Biosyst. Eng., v.12, p.327-332, 2018.

PRATES, R.C.; REZENDE, H.C.; LANA, A.M.Q. et al. Heart rate of Mangalarga Marchador mares under march test and supplemented with chrome. Rev. Bras. Zootec., v.38, p.916-922, 2009.
SIMON, E.L.; GAUGHAN, E.M.; EPP, T.; SPIRE, M. Influence of exercise on thermographically determined surface temperatures of thoracic and pelvic limbs in horses. J. Am. Vet. Med. Assoc., v.229, p.19401944, 2006.

STEWART, M.; WEBSTER, J.R.; SCHAEFER, A.L. et. al. Infrared thermography as a noninvasive tool to study animal welfare. Anim. Welf., v.14, p.319-325, 2005.

TRINDADE, P.H.E.; FERRAZ, G.C.; LIMA, M.L.P. et al. Eye surface temperature as a potential indicator of physical fitness in ranch horses. J. Equine Vet. Sci., v.75, p1-8, 2019

YARNELL, K.; FLEMING, J.; STRATTON, T.D.; BRASSINGTON, R. Monitoring changes in skin temperature associated with exercise in horses on a water treadmill by use of infrared thermography. J. Therm. Biol., v.45, p.110-116, 2014. 